\title{
SAFETY ASSESSMENT OF Bacillus thuringiensis- BASED PRODUCTS USING EYE/OCULAR IRRITATION ON RABBITS
}

\author{
MOHD NAJIB AHMAD*; SITI RAMLAH AHMAD ALI*; MOHAMED MAZMIRA MOHD MASRI*; NORMAN \\ KAMARUDIN*; AHMAD KUSHAIRI* and MOHD ZAINI ASMAWI**
}

\begin{abstract}
To register with the National Pesticide Board, Malaysia, a pesticide must undergo laboratory testing for short-term and long-term health effects. Laboratory animals such as rabbits are tested with high doses of Bacillus thuringiensis (Bt) products to assess the potential to produce lesions or reversal effects on eyes. The objective of this study was to investigate the effect of Bafog-1 (S) and Ecobac-1 (EC) against young New Zealand albino rabbit's eye or the potential of Bt products to cause eye or ocular irritation. The test was conducted according to the Guidelines of International Organisation for Standardisation 10993-10, Test for Irritation and Sensitisation. The results showed that Bafog-1 (S) is not an irritant to rabbits, whereas, Ecobac-1 (EC) produced irritation that was reversal after $120 \mathrm{hr}$ of instillation. The Bt as an environmental-friendly microbial insecticide was generally non-toxic to human, domestic animals and vertebrates. Therefore, Bt is recommended to be used as a safe microbial insecticide for controlling bagworm in oil palm plantation.
\end{abstract}

Keywords: Bacillus thuringiensis, Bafog-1 (S), Ecobac-1 (EC), eye irritation, pesticides, bagworm, oil palm.

Date received: 2 July 2015; Sent for revision: 3 July 2015; Received in final form: 18 September 2015; Accepted: 30 January 2016.

\section{INTRODUCTION}

Bacillus thuringiensis (Bt) is known as a spore-forming bacterial insect pathogen and it has been extensively studied in various laboratories worldwide for its potential as an effective biological control agent against almost all insect pests in the world, including the bagworm (Lepidoptera: Psychidae) (Ramlah Ali and Mohd Basri, 1997; Ramlah Ali, 2000; Ramlah

\footnotetext{
* Malaysian Palm Oil Board,

6 Persiaran Institusi, Bandar Baru Bangi,

43000 Kajang,Selangor, Malaysia.

E-mail: mnajib@mpob.gov.my

** School of Pharmaceutical Science,

Universiti Sains Malaysia,

11800 Minden, Pulau Pinang, Malaysia.
}

Ali and Mahadi, 2001). The Bt as a gram-positive bacteria will produce crystalliferous proteins during sporulation which are toxic to specific insect pests (Roh et al., 2007; Xavier et al., 2007). These activated toxins, known as delta-endotoxins, bind to the gut receptors and cause osmotic lyses and death of the bagworm (Ramlah Ali et al., 2009). Nowadays, the broad-spectrum insecticides are widely used for controlling insect pests which affect food production and agricultural crops. The residues of these insecticides cause toxic effects on non-target organisms (Meher et al., 2002) and the uncontrolled usage of insecticides has led to the emergence of resistant pest variants. Eventually, in the last three decades, efforts are being made to develop microbial insecticides from insect pathogenic bacilli such as $B$. thuringiensis, B. lentimorbus and B. sphaericus 
as biological control agents. They are among the widely known and employed bacteria for controlling agricultural insect pests (Sutherland and Khoo, 1987).

Basically, the general requirement for registration of pesticides with the National Pesticide Board is to conduct laboratory testing for short-term and longterm health effects. For example, laboratory animals are fed with high doses of tested chemicals to assess the toxic effects and the results will help scientists to evaluate and identify the effect of these chemicals on humans, domestic animals and wildlife (National Pesticide Information Centre, 2000).

Toxic effects involving eyes or vision are very important side-effects of chemical or biological substances used in the industry, especially cosmetics. It has frequently evaluated the result of eye irritation test by using rabbits as well as the nature of the most crucial effects that can lead to serious eye damage (Ingrid et al., 2005). Eye irritation is defined as the production of changes in the eye following the application of test substance to the anterior surface of the eye, which are fully reversible within 21 days of application (http:/ / alttox.org). The Bt is found not to be an eye irritant on rabbits (Donghai et al., 2008). There is very slight irritation from inhalation in test animals which may be caused by the physical rather than the biological properties of the Bt formulation tested. The Bt has not been shown to have any chronic toxicity or any carcinogenic effects. There are also no indications that $\mathrm{Bt}$ causes reproductive effects or birth defects in mammals (Glare and O'Callaghan, 2000; Carrie, 1994).

The Malaysian Palm Oil Board (MPOB) has developed $\mathrm{Bt}$ products through an intensive research for controling bagworms (Najib et al., 2008; 2013; 2014; 2015; Mazmira et al., 2011). Two different formulations of products were developed, namely Bafog-1 (S) and Ecobac-1 (EC). This study reports the effect of MPOB Bt1 products, Bafog-1 (S) and Ecobac-1 (EC) against the young New Zealand albino rabbits eye/ocular irritation.

\section{MATERIALS AND METHODS}

\section{Preparation of Bt Products}

Bafog-1 (S) is a solution (S) and Ecobac-1 $(\mathrm{EC})$ is an emulsified concentrate (EC), consisting of indigenous Bt (MPOB Bt1). Both products were produced at the Microbial Technology and Engineering Centre (MICROTEC), MPOB, Bangi, Selangor, Malaysia. The Bt products were prepared after $48 \mathrm{hr}$ of fermentation using the laboratory prepared medium, AgroNat-7 (Patent No. PI2011000307) (Najib et al., 2014; 2015; Ramlah Ali et al., 2011). The fermentation was conducted in a bioreactor with a working volume of 300 litres and temperature of $30^{\circ} \mathrm{C}$. Both Bt products were produced using a vacuum evaporator and sedimentation technique as reported by Najib et al. (2012; 2014; 2015).

\section{Animals}

Six eight-week old young New Zealand albino rabbits obtained from the Animal Research and Service Centre (ARASC), Universiti Sains Malaysia (USM), Pulau Pinang, Malaysia, were acclimatised for five days before use. The weight of the rabbits used was 2.0 to $3.0 \mathrm{~kg}$. The number of rabbits used per Bt product was $3(n=3)$ or three rabbits per concentration and with a single concentration.

\section{Treatments}

Approximately $0.1 \mathrm{ml}$ of the undiluted $\mathrm{Bt}$ products was instilled using a sterilised syringe into the lower conjunctival sac of the right eye with the left eye (untreated) serving as control (Donghai et al., 2008). The eyelid was held together for approximately $1 \mathrm{~s}$ after instillation of the Bt products. The original concentrations of Bafog-1 (S) solution and Ecobac-1 (EC) used were $7.4 \times 10^{11} \mathrm{cfu} \mathrm{ml}^{-1}$ and $4.5 \times 10^{11} \mathrm{cfu}$ $\mathrm{ml}^{-1}$, respectively.

\section{Observation}

Both eyes of the rabbits were examined at 1, 24, 48 and $72 \mathrm{hr}$ after receiving a single instillation of Bt products. Extended observation was carried out if there was persistent corneal involvement or other ocular irritation in order to determine the progress of the lesions or their reversal.

\section{RESULTS AND DISCUSSION}

\section{Effect of Bafog-1 (S) on Ocular/eye Irritation of Rabbits}

The result showed that Bafog-1 (S) was proven as non-irritant to the rabbit's eyes at the highest concentration of $7.4 \times 10^{11} \mathrm{cfu} \mathrm{ml}^{-1}$ (Table 1). Bafog-1 (S) led to conjunctival redness at 1 and $24 \mathrm{hr}$ after a single instillation of one eye for all tested rabbits. Whereas, for chemosis, the Bt product only caused swelling above normal condition at $1 \mathrm{hr}$ after instillation for all tested rabbits.

\section{Effect of Ecobac-1 (EC) on Ocular/eye Irritation of Rabbits}

The results on eye irritation experiment indicated that Ecobac-1 (EC) produced irritant reversal after $120 \mathrm{hr}$ of instillation at the highest concentration of $4.5 \times 10^{11} \mathrm{cfu} \mathrm{ml}^{-1}$ (Table 2). The Ecobac-1 (EC) 
TABLE 1. THE EFFECT OF BAFOG-1 (S) ON EYE/OCULAR IRRITATION OF RABBITS

\begin{tabular}{|c|c|c|c|c|c|c|c|}
\hline \multirow{3}{*}{ Evaluation } & \multirow{3}{*}{$\begin{array}{c}\text { Rabbit's No. } \\
\text { Sex } \\
\text { Treatment (hr) }\end{array}$} & \multirow{2}{*}{\multicolumn{2}{|c|}{$\begin{array}{c}1 \\
\text { Female }\end{array}$}} & \multirow{2}{*}{\multicolumn{2}{|c|}{$\begin{array}{c}2 \\
\text { Male }\end{array}$}} & \multirow{2}{*}{\multicolumn{2}{|c|}{$\begin{array}{c}3 \\
\text { Male }\end{array}$}} \\
\hline & & & & & & & \\
\hline & & Test & Control & Test & Control & Test & Control \\
\hline \multirow[t]{4}{*}{ Cornea } & 1 & 0 & 0 & 0 & 0 & 0 & 0 \\
\hline & 24 & 0 & 0 & 0 & 0 & 0 & 0 \\
\hline & 48 & 0 & 0 & 0 & 0 & 0 & 0 \\
\hline & 72 & 0 & 0 & 0 & 0 & 0 & 0 \\
\hline \multirow[t]{4}{*}{ Iris } & 1 & 0 & 0 & 0 & 0 & 0 & 0 \\
\hline & 24 & 0 & 0 & 0 & 0 & 0 & 0 \\
\hline & 48 & 0 & 0 & 0 & 0 & 0 & 0 \\
\hline & 72 & 0 & 0 & 0 & 0 & 0 & 0 \\
\hline \multirow{4}{*}{$\begin{array}{l}\text { Conjunctival } \\
\text { redness }\end{array}$} & 1 & 1 & 0 & 1 & 0 & 1 & 0 \\
\hline & 24 & 1 & 0 & 1 & 0 & 1 & 0 \\
\hline & 48 & 0 & 0 & 0 & 0 & 0 & 0 \\
\hline & 72 & 0 & 0 & 0 & 0 & 0 & 0 \\
\hline \multirow[t]{4}{*}{ Chemosis } & 1 & 1 & 0 & 1 & 0 & 1 & 0 \\
\hline & 24 & 0 & 0 & 0 & 0 & 0 & 0 \\
\hline & 48 & 0 & 0 & 0 & 0 & 0 & 0 \\
\hline & 72 & 0 & 0 & 0 & 0 & 0 & 0 \\
\hline
\end{tabular}

Note: Evaluation according to the number in Table 1.

$\begin{array}{llll}\text { Cornea: } & \text { Iris: } & \text { Redness: } & \text { Chemosis: } \\ \text { Normal - } 0 & \text { Normal - } 0 & \text { Normal - } 0 & \text { Normal - } 0 \\ \text { Diffused capacity - } 1 & \text { Congestion - } 1 & \text { Some vessel injected }-1 & \text { Any swelling above normal }-1 \\ \text { Iris slightly obscured - } 2 & \text { Haemorrhages }-2 & \text { Crimson red }-2 & \text { Partial lid inversion }-2 \\ \text { Nacreous - } 3 & \text { Cut off point }=0-2 & \text { Beefy red - } 3 & \text { Lids half closed }-3 \\ \text { Iris not discernible }-4 & & \text { Cut off point }=0-3 & \text { Lids more than half closed }-4 \\ \text { Cut off point }=0-4 & & & \text { Cut off point }=0-4\end{array}$

led to conjunctival redness at $1 \mathrm{hr}$ until $96 \mathrm{hr}$ of single instillation in all tested rabbits. Furthermore, chemosis in the Ecobac-1 (EC) resulted in half close of lids for all tested rabbits at $1 \mathrm{hr}$ post-instillation. At $24 \mathrm{hr}$ post-instillation, rabbit No. 2 led to partial lid inversion until $48 \mathrm{hr}$ of the single instillation. However, at $72 \mathrm{hr}$ after the single instillation, the eyes of all tested rabbits had slowly recovered from partial lid inversion to swelling above normal condition until $96 \mathrm{hr}$ of the single instillation. Finally, after $120 \mathrm{hr}$ of the single instillation, the eyes became normal or the Ecobac-1 (EC) produced irritant reversal after $120 \mathrm{hr}$ of the single instillation.

Ecobac-1 (EC) is an emulsified concentrate produced and mixed with an inert ingredient during formulation. Paraffin liquid is included as one of the component in the formulation. According to the Material Safety Data Sheet (2004) and the National Pesticide Information Centre (2000), in potential health effects, eye irritation may occur with exposure to concentrated vapours or contact with the paraffin liquid. Based on this fact, Ecobac-1 (EC) contained paraffin liquid that may cause eye irritation to young New Zealand albino rabbits and the Bt was found not to be an eye irritant on test rabbits (Donghai et al., 2008). In other words, there was a very slight irritation from inhalation in test animals which may be caused by the additional of an inert ingredient during formulation rather than the biological properties of the $\mathrm{Bt}$ formulation tested (Glare and O'Callaghan, 2000; Carrie, 1994).

\section{CONCLUSION}

It is concluded that Bafog-1 (S) produced no eye irritation to rabbits and Ecobac-1 (EC) produced irritant reversal after $120 \mathrm{hr}$ of instillation. Ecobac-1 (EC) with emulsifiable formulation requires safety precaution during handling and mixing. However, $\mathrm{Bt}$ as an environmental-friendly microbial insecticide is non-toxic to humans, domestic animals and aquatic fish.

\section{ACKNOWLEDGEMENT}

The authors would like to thank the Director-General of MPOB for permission to publish this article. The 
TABLE 2. THE EFFECT OF ECOBAC-1 (EC) ON EYE/OCULAR IRRITATION OF RABBITS

\begin{tabular}{|c|c|c|c|c|c|c|c|}
\hline \multirow{3}{*}{ Evaluation } & \multirow{3}{*}{$\begin{array}{c}\text { Rabbit's No. } \\
\text { Sex } \\
\text { Treatment (hr) }\end{array}$} & \multirow{2}{*}{\multicolumn{2}{|c|}{$\frac{1}{\text { Female }}$}} & \multirow{2}{*}{\multicolumn{2}{|c|}{$\frac{2}{\text { Male }}$}} & \multirow{2}{*}{\multicolumn{2}{|c|}{$\frac{3}{\text { Male }}$}} \\
\hline & & & & & & & \\
\hline & & Test & Control & Test & Control & Test & Control \\
\hline \multirow{7}{*}{ Cornea } & 1 & 0 & 0 & 0 & 0 & 0 & 0 \\
\hline & 24 & 0 & 0 & 0 & 0 & 0 & 0 \\
\hline & 48 & 0 & 0 & 0 & 0 & 0 & 0 \\
\hline & 72 & 0 & 0 & 0 & 0 & 0 & 0 \\
\hline & 96 & 0 & 0 & 0 & 0 & 0 & 0 \\
\hline & 120 & 0 & 0 & 0 & 0 & 0 & 0 \\
\hline & 144 & 0 & 0 & 0 & 0 & 0 & 0 \\
\hline \multirow{7}{*}{ Iris } & 1 & 0 & 0 & 0 & 0 & 0 & 0 \\
\hline & 24 & 0 & 0 & 0 & 0 & 0 & 0 \\
\hline & 48 & 0 & 0 & 0 & 0 & 0 & 0 \\
\hline & 72 & 0 & 0 & 0 & 0 & 0 & 0 \\
\hline & 96 & 0 & 0 & 0 & 0 & 0 & 0 \\
\hline & 120 & 0 & 0 & 0 & 0 & 0 & 0 \\
\hline & 144 & 0 & 0 & 0 & 0 & 0 & 0 \\
\hline \multirow{7}{*}{$\begin{array}{l}\text { Conjunctival } \\
\text { redness }\end{array}$} & 1 & 1 & 0 & 1 & 0 & 1 & 0 \\
\hline & 24 & 1 & 0 & 1 & 0 & 1 & 0 \\
\hline & 48 & 1 & 0 & 1 & 0 & 1 & 0 \\
\hline & 72 & 1 & 0 & 1 & 0 & 1 & 0 \\
\hline & 96 & 1 & 0 & 1 & 0 & 1 & 0 \\
\hline & 120 & 0 & 0 & 0 & 0 & 0 & 0 \\
\hline & 144 & 0 & 0 & 0 & 0 & 0 & 0 \\
\hline \multirow{7}{*}{ Chemosis } & 1 & 3 & 0 & 3 & 0 & 3 & 0 \\
\hline & 24 & 3 & 0 & 2 & 0 & 3 & 0 \\
\hline & 48 & 1 & 0 & 2 & 0 & 2 & 0 \\
\hline & 72 & 1 & 0 & 1 & 0 & 1 & 0 \\
\hline & 96 & 1 & 0 & 1 & 0 & 1 & 0 \\
\hline & 120 & 0 & 0 & 0 & 0 & 0 & 0 \\
\hline & 144 & 0 & 0 & 0 & 0 & 0 & 0 \\
\hline
\end{tabular}

Note: Evaluation according to the number in Table 2.

$\begin{array}{llll}\text { Cornea: } & \text { Iris: } & \text { Redness: } & \text { Chemosis: } \\ \text { Normal }-0 & \text { Normal }-0 & \text { Normal }-0 & \text { Normal }-0 \\ \text { Diffused capacity }-1 & \text { Congestion }-1 & \text { Some vessel injected }-1 & \text { Any swelling above normal - } 1 \\ \text { Iris slightly obscured }-2 & \text { Haemorrhages }-2 & \text { Crimson red }-2 & \text { Partial lid inversion }-2 \\ \text { Nacreous }-3 & \text { Cut off point }=0-2 & \text { Beefy red }-3 & \text { Lids half closed }-3 \\ \text { Iris not discernible }-4 & & \text { Cut off point }=0-3 & \text { Lids more than half closed }-4 \\ \text { Cut off point }=0-4 & & & \text { Cut off point }=0-4\end{array}$


authors would also like to thank members of the School of Pharmaceutical, USM for conducting the experiment. Last but not least to the members of the Microbial Bioprospecting and Bioprocessing Group, MPOB who were involved in assisting in the production of the Bt products.

\section{REFERENCES}

CARRIE, S (1994). Bacillus thuringiensis (Bt) insecticide fact sheet. J. Pesticide Reform., 14: 1-18. www.mindfully.org/GE/Bacillus-thuringiensis-Bt. htm

DONGHAI, P; CHENFEI, Z; SHOUWEN, C; LIFANG, R; ZINIU, Y and MING, S (2008). Toxicological safety assessment of genetically modified Bacillus thuringiensis with additional N-Acyl homoserine lactonase gene. Environmental Toxicology and Chemistry, 27: 188-195. www.researchgate.net/publication/5755929_Toxicological_safety

GLARE, T R and O'CALLAGHAN, M (2000). Bacillus thuringiensis: Biology, Ecology and Safety. United States Department of Agriculture, San Diego, USA. http://www.bt.ucsd.edu/bt_safety.html http: / / alttox.org/mapp/ toxicity-endpoints-tests / eye-irritationcorrosion/

INGRID, G; MANFRED, L and HORST, S (2005). Assessment of the eye irritating properties of chemicals by applying alternatives to the draize rabbit eye test: the use of QSARs and in vitro tests for the classification of eye irritation. ALTA, 33: 215237. www.researchgate.net/publication/7583111_ Assessment_of_the_eye

MATERIAL SAFETY DATA SHEET (2004). Light Liquid Paraffin (White Mineral Oil) (revision date: 05.05.2004). Www.paraffinoils.com / LightLiquid-Paraffin-Oil-MSDS.doc

MAZMIRA, M M M; SITI RAMLAH, A A; NAJIB, M A; NORMAN, K; KUSHAIRI, A D and BASRI, M W (2011). Pest management of bagworm in Southern Perak by aerial spraying with Bacillus thuringiensis. Oil Palm Bulletin No. 65: 24-33.

MEHER, S M; BODHANKAR, S L; ARUNKUMAR; DHULEY, J N, KHODAPE, D J and NAIK, S R (2002). Toxicity studies of microbial insecticide Bacillus thuringiensis var. kenyae in rats, rabbits and fish. International J. Toxicology, 21: 99-105. http: / / academic.research.microsoft.com / Author / 27362082 / jayant-n-dhuley

NAJIB, M A; SITI RAMLAH, A A; MAZMIRA, M $\mathrm{M} M$ and BASRI, M W (2008). Lepcon-1: flowable concentrate of Bacillus thuringiensis, MPOB Bt1 for bagworm control. MPOB Information Series. No. 403. palmoilis.mpob.gov.my / publications / TOT / TT403.pdf

NAJIB, M A; SITI RAMLAH, A A; MAZMIRA, M M M and BASRI, M W (2012). Effect of Bacillus thuringiensis, Lepcon-1, Bafog-1 (S) and Ecobac-1 (EC) against oil palm pollinator, Elaeidobius kamerunicus and beneficial insects associated with Cassia cobanensis. J. Oil Palm Res. Vol. 24: 1442-1447.palmoilis.mpob.gov.my / publications / joprv24aug2012-Najib.pdf

NAJIB, M A; SITI RAMLAH, A A; MAZMIRA, M M $M$ and BASRI, M W (2013). Efficacy of Bafog-1 (S), formulated local Bacillus thuringiensis for controlling bagworm, Pteroma pendula (Lepidoptera: Psychidae). J. Oil Palm Res. Vol. 7: 228-234. palmoilis.mpob.gov. my/publications/joprv25aug2013-Najib.pdf

NAJIB, MA;SITIRAMLAH, AA;MAZMIRA, MMM and NORAZAH, Z (2014). Lepcon-1, Bafog-1(S) and Ecobar-1(EC), Bacillus thuringiensis based products are not toxic against the freshwater fish, Tilapia nilotica. J. Oil Palm Res. Vol. 26(4): 317-320. palmoilis. mpob.gov.my/publication / jopr26dec2014-Najib. pdf

NAJIB, M A; SITI RAMLAH, A A; MAZMIRA, M M $\mathrm{M}$ and ZAINI, M A (2015). Effect of Bafog-1 (S) and Ecobac-1 (EC), Bacillus thuringiensis based-products against rats, Sprague-Dawley. J. Oil Palm Res. Vol. 27(1): 30-38. palmoilis.mpob.gov.my/publications / joprv27march2015-Najib.pdf

NATIONAL PESTICIDE INFORMATION CENTRE (NPIC) (2000). Bacillus thuringiensis. NPTN General Fact Sheets. Oregon State University and US Environmental Protection Agency. www.npic.orst. edu/factsheets / BTgen.pdf

RAMLAH ALI, A S (2000). Mechanism of Action of Bacillus thuringiensis $\delta$-endotoxins: Studies on Binding of $\delta$-endotoxins in Brush Border Membrane Vesicle of Metisa plana (Walker). Ph.D thesis, Universiti Kebangsaan Malaysia. www.mpob.gov.my/index. php?option $=$ com_content $\&$ view $=$ article\&id $=737 \% 3$

RAMLAH ALI, A S and MAHADI, N M (2001). Binding of $\delta$-endotoxin of Bacillus thuringiensis to bbmv from susceptible and resistant Metisa plana. Paper presented at the $4^{\text {th }}$ Rim Pacific Conference on the Biotechnology of Bacillus thuringiensis and its Environmental Impact, 11-15 November 2001, Canberra, Australia. palmoilis.mpob.gov.my/ publications / TOT/tt133.pdf

RAMLAH ALI, A S and MOHD BASRI, W (1997). A local Bacillus thuringiensis, SRBT1 with potential for controlling Metisa plana (Wlk). Elaeis, 9(1): 34-45. 
www.mpob.gov.my/html/publications / bulletin0_ pelapast.htm

RAMLAH ALI, A S; NAJIB, M A; MAZMIRA, M M M and BASRI, M W (2009). Ecobac-1 (EC): emulsified concentrate Bacillus thuringiensis for controlling bagworm outbreak by aerial spraying. $M P O B$ Information Series No. 461. palmoilis.mpob. gov.my/publications/TOT/TT-420.pdf

RAMLAH ALI, A S; NAJIB, M A and MAZMIRA, M M M (2011). Method of producing microbial insecticide. Malaysian patent application. Patent application No. PI2011000307.

ROH; YUL, J; CHOI, J Y; LI, M S; JIN, B R and JE, Y $\mathrm{J}$ (2007). Bacillus thuringiensis as a specific, safe, and effective tool for insect pest control. J. Microbiology and Biotechnology, 17(4): 547-559. www.sciencedirect. com/science/ article/ pii/ S0022201113000669
STANDING COMMITTEE ON BIOCIDAL PRODUCTS (2010). Assessment Report on Bacillus thuringiensis subsp. israelensis Serotype H-14 Strain AM65-52 to Directive 98/8/EC. p. 1-48. faolex.fao. org/docs/pdf/eur120845.pdf

SUTHERLAND, D J and KHOO, B K (1987). The biopesticides Bacillus thuringiensis israelensis and Bacillus sphaericus in the control of mosquitoes. Development of Industrial Microbiology, 28: 55-61. link. springer.com / article/ 10.1007\%2Fs00284-008-9159-z

XAVIER, R; NAGARATHINAM， P; GOPALAKRISHNAN; MURUGAN, $\mathrm{V}$ and JAYARAMAN, K (2007). Isolation of lepidopteran active native Bacillus thuringiensis strains through PCR panning. Asia Pacific J. Molecular Biology and Biotechnology, 15(2): 61-67. www.twirpx.com/files/biology/microbiology/ff.pdf 